\title{
The Effect of Ascariosis Treatment and Health Education on The Cognitive Function of Primary School Children
}

\author{
Pinardi Hadidjaja*, Harun Mahfudin*, Is Suhariah Ismid,* Engelina Bonang**, Risma Yunandi**, and \\ Derry B. Hartana**
}

\begin{abstract}
Abstrak
Di daerah kumuh di Jakarta, infeksi Ascaris lumbricoides masih tinggi terutama pada anak sekolah dasar dengan prevalensi berkisar antara 60 - 90\%. Hubungan antara infeksi cacing dengan status gizi dan hasil evaluasi belajar telah lama diketahui. Penelitian ini dilakukan di Kecamatan Koja dan Kecamatan Pademangan, Jakarta Utara pada murid sekolah dasar yang berumur 6 - 8 tahun. Sebelum intervensi, dilakukan pemeriksaan data dasar tentang infeksi cacing, keadaan sosial ekonomi, beberapa penelitian epidemiologi dan fungsi kognitif. Tes fungsi kognitif dilakukan secara perorangan. Tes statistik dilakukan dengan memakai SPSS (Statistical Program for Social Sciences). Anak-anak dibagi menjadi 4 kelompok. Pada kelompok I diberikan obat cacing, kelompok II penyuluhan kesehatan, kelompok III obat cacing dan penyuluhan kesehatan. Sedangkan pada kelompok IV diberikan pengobatan memakai plasebo. Pemeriksaan data dasar diulangi 6 bulan kemudian, kecuali untuk data sosial ekonomi dan epidemiologi. Hasil penelitian menunjukkan bahwa dari jumlah 483 orang anak yang dikumpulkan dalam penelitian ini, ternyata hanya terdapat 336 anak yang mempunyai data lengkap dan dapat diikut sertakan dalam tes analisis kovarian. Hasilpengamatan lingkungan dan sosio-ekonomi telah diberikan secara singkat. Hasil tes kognitifmenunjukkan adanya perbedaan bermakna pada kelompokyang diberimebendazol terhadap tes "Coloured Progressive Matrices" dan tes "coding" yang berarti adanya kemajuan dalam proses belajar, konsentrasi dan koordinasi motorik penglihatan 6 bulan setelah pemberian pengobatan. Ternyata infeksi A. lumbricoides walaupun ringan dapat berpengaruh terhadap fungsi kognitif anak sekolah dasar.
\end{abstract}

\begin{abstract}
The prevalence rate of Ascaris lumbricoides infection in urban slums of Jakarta is still high, especially in primary school children, ranging from 60 to $90 \%$. An association between helminthic infection and educational achievement has long been recognized. This study was carried out in the northern part of Jakarta, namely the Koja and Pademangan district where the target schools were situated. In this study primary school children aged $6-8$ year were used. Ascariosis treatment and health education were used for intervention. Before intervention basic data which consisted of A. lumbricoides infection, socio-economic status, epidemiology and cognitive function were collected. The cognitive function test was done individually. For statistical analysis SPSS (Statistical Program for Social Sciences) was used. The children were then divided into four groups. Group I was given anthelminthic, and group II health education. Group III was given a combination of treatment and health education, whereas in group IV placebos were given. The same basic data were collected 6 months after intervention, except for the epidemiological and socio-economical data. The result of the study showed that a total of 483 students were recruited in the study. But not all these students had complete data. Only 336 students participated in the analysis of Covariance. The results of environmental, and socio-economical studies were described. The result of the cognitive test showed that the Mebendazole group revealed significant improvement on the Coloured Progressive Matrices and coding tests after intervention. This means that intervention did improve their ability in learning,concentration, and a better eye-hand coordination 6 months after intervention. This result showed that even slight infection of Ascaris lumbricoides showed an influence on the cognitive function of primary school children.
\end{abstract}

Keywords : Ascariosis, Mebendazole, Health education, Cognitive function

\section{INTRODUCTION}

Prevalence rates of Ascaris lumbricoides infection in urban areas of Jakarta, Indonesia are still high, espe-

\footnotetext{
* Department of Parasitology, Faculty of Medicine University of Indonesia, Jakarta, Indonesia

** Department of General and Experimental Psychology, Faculty of Psychology, University of Indonesia, Jakarta, Indonesia
}

cially in primary school children, ranging from 60 to $90 \%{ }^{1,2}$ School-age children were reported to have the highest prevalences and intensities of these geohelminth infections, ${ }^{3}$ and the resulting morbidity involved undernutrition and iron-deficiency anemia. ${ }^{4}$ The association of iron deficiency anemia and learning capability was reported in Indonesia resulting in impaired cognitive function. ${ }^{5,6,7,8} \mathrm{An}$ association between helminthic infection and educational achieve- 
ment has long been recognized; ${ }^{9,10}$ however it is unclear whether the relation is causal or resulting from covariances of socio-economic status. ${ }^{11}$ This paper reports the results of a study using an experimental design with 2 kinds of intervention, namely the administration of anthelmintics and health-education. The objective of this study is to examine whether the infection of A.lumbricoides in school children is causally correlated with their cognitive function.

\section{MATERIALS AND METHODS}

\section{The study area}

The study area was located in North Jakarta, in the subdistricts of Koja and Pademangan, slum areas where environmental sanitation as well as personal hygienic conditions were poor.

\section{Selection of samples}

Four schools were selected in this study. These schools were randomly assigned to four treatments : anthelmintic (mebendazole), health education, health education plus mebendazole and placebo. A group of uninfected children is needed for comparison purposes. Stool samples of this group were negative for A.lumbricoides eggs before and after the intervention. They were in the same schools as the infected children who received the same treatment. Approximately 1000 children were targeted for parasitological, nutritional and psychological examination before and after intervention. The interval between these two examinations was six months. The objective of the research is to study the effect of $A$. lumbricoides infection on the cognitive function. As pure A. lumbricoides infection is rare in Indonesia, therefore mixed-infection with $A$. lumbricoides and Trichiuris trichiura could not be avoided. In order to eliminate the influence of $T$. trichiura infection on the cognitive function, children with high burdens of T.trchiura eggs ( $<500 \mathrm{epg}$ ) were excluded from the study. Nokes et al ( 1992 ) reported that only heavy infection of $T$. trichiura caused a decrease in cognitive function. ${ }^{10}$ The first data were used as baseline, whereas the second data collected after the intervention were used as the post-intervention data.

\section{Socio-economic and epidemiologic data collection}

Socio-economic and epidemiological data were collected from the mothers/fathers of the children by means of questionaires. The questions were targeted on the educational and employment status. For the epidemiological point of view, only the prevalence of A.lumbricoides infection, the description of the environment, the existence of latrines and water sources were recorded.

\section{Parasitological study}

Stool samples were requested from all the school children, aged 6 to 8 years and examined in the Department of Parasitology using the Kato-Katz quantitative thick smear technic, before and 6 months after intervention. Children with $A$. lumbricoides infection with number of eggs per gram of faeces, without or with any T.trichiura infection which were less than 500 eggs per gram of faeces, normal I.Q. and no severe malnutrition were taken as samples. The intervention was carried out right after the collection of the baseline data. The students were divided into five groups, which consisted of four groups of $A$. lumbricoides positive and one group of $A$. lumbricoides negative children.

The first group was treated with mebendazole, a single dose of $500 \mathrm{mg}$; drug administration was witnessed by one of the researchers.

The second group was given health education on ascariosis. Health education was given to this group weekly for six months by teachers who were trained before. Monitoring of health education was done by the research team. The children were informed concerning the mode of $A$. lumbricoides infection as well as how to prevent worm infection, emphasized on the improvement of environmental sanitation as well as personal hygiene.

The third group was given a single dose of $500 \mathrm{~g}$ mebendazole and health education.

The fourth group was the control group who was given the placebo tablet which had the same size, form as well as the same colour as the mebendazole tablet.

In this study, each school received one kind of treatment. The schools were selected at random and the treatments were assigned randomly to the schools. The group who received placebo could be considered as the control group.

\section{Psychological examination}

In order to evaluate the improvement of cognitive function of the children, cognitive tests were performed before and after interventions. 
The cognitive tests chosen to measure these functions were :

1. Ravens Coloured Progressive Matrices

The test measures the ability to form comparisons, to reason by analogy and to organize spatial perceptions into systematically related wholes.

2. Three subtests from Wechsler Intelligence Scale for Children (WISC) :

a) Digit Span Forward and Backward

These tests measure short-term memory and attention.

b) Arithmethic

This test is not only on mathematical knowledge, but also on mental computation and concentration.

c) Coding

The test measures the ability to learn and involves speed and accuracy of eye-hand coordination, attentional skills and short term memory.

\section{Oddity}

Oddity learning is the test used by Pollit et al. and Soewondo, ${ }^{12,13}$ in their researches on malnutrition and iron-deficiency. The test measures the ability to learn concept i.e. the concept "odd". This test evaluates discrimination of learning which is related to attention, memory and learning capability.

The cognitive tests were carried out individually for each student.

\section{Analysis}

The statistical procedures used were ANOVA and Analysis of Covariance where the covariates were entered first (experimental method). All analysis were done by using SPSS (Statistical Program for Social Sciences). Statistical significance was assumed at $\mathrm{p}<$ 0.05 .

\section{RESULTS AND DISCUSSION}

A total of 483 students were considered qualified for the analysis, as they had participated in both the pre and post test.

However only 336 students with complete data were included in the analysis of covariance : 54 students of group I, 49 students in the health education group, 48 students in the combined treatment (health education plus mebendazole) group, and 99 students in the placebo group.

The result of the observation on the environmental situation showed that the study areas were slums with a very poor sanitary condition. Irrigation ditches seemed to be the main place for defecation. The ditches were full of garbage and human faeces polluted the river water. But if we considered the existence of the number of latrines in the area, the latrines consisted of $27.4 \%$ community latrines, and $71.9 \%$ of house-hold latrines. Among the population $24.2 \%$ bought their drinking water, $74.0 \%$ used tap water, $1.4 \%$ obtained water from open wells whereas $0.4 \%$ used water from water pumps. $0.7 \%$ of the population defecated on the river-side. Data on education of the mothers showed that $60.9 \%$ were in the group with the lowest level (primary school graduate or lower), and $37.4 \%$ in the middle class group (secondary school) whereas only $1.7 \%$ had a higher education.

The result of the parasitological examinations showed that the prevalence rate of group I was $62.6 \%$ for ascariosis, and group II had a prevalence rate of $49.1 \%$ and were given health education. The third group had a prevalence rate of $72.8 \%$, and were treated with mebendazole and health education. The last group, the placebo group had a prevalence rate of $56.2 \%$.

The means of the four groups with pre- and post intervention on all the variables in the study groups are shown in Table 1.

Table 1 showed that the greatest decrease of infection of both worms happened in the group which was given only mebendazole. The groups which were given health education only and a combination of health education plus mebendazole also showed a decrease of worm infection, but the decrease was not as much as that in the mebendazole group. Two other variables which showed significant intervention effect were PM-C and Coding. The highest increase in scores was noticed in the mebendazole group. Before the intervention this group had the lowest means for PM-C and Coding compared to the other groups (Table 1). The differential effect of interventions was almost significant on Oddity with the highest mean difference of score in the mebendazole group, while before the intervention this group had the lowest mean for oddity. On account of the fact that the post-intervention means for PM-C, Coding and Oddity of the mebendazole group were highest, it could be concluded that the children with low scores in the mebendazole group benefitted most from the treatment. Table 1 also showed that the improvement from pre- to post-test on the cognitive tests in the placebo group. was much lower in comparison to the mebendazole group. In the group who received only health education it was evident that there was no significant improvement, this might be due to the short term implementation of the 
Table 1. Means on all the variables of pre- and post-intervention measurements in five groups.

\begin{tabular}{lrrrrrrrrrr}
\hline & \multicolumn{2}{c}{ Mebendazole } & \multicolumn{2}{c}{ Health ed. } & \multicolumn{2}{c}{ He+Meb } & \multicolumn{2}{c}{ Placebo } & \multicolumn{2}{c}{ Neg. } \\
VARIABEL & Pre & Post & Pre & Post & Pre & Post & Pre & Pos & Pre & Post \\
\hline Educ.of mother* & 2 & & 1 & & 1 & & 2 & & 2 & \\
Asc. lumbr* & 2435 & 657 & 1264 & 812 & 1679 & 819 & 1898 & 1919 & 0 & 0 \\
Trich. T.* & 143 & 58 & 88 & 82 & 104 & 37 & 113 & 160 & 56 & 47 \\
PM - C* & 14 & 17 & 18 & 18 & 17 & 19 & 16 & 18 & 16 & 18 \\
Arithm & 5 & 6 & 6 & 6 & 6 & 6 & 5 & 6 & 5 & 6 \\
Coding* & 31 & 44 & 37 & 45 & 39 & 44 & 37 & 43 & 38 & 44 \\
DS Forw* & 4 & 5 & 5 & 5 & 5 & 5 & 4 & 5 & 5 & 5 \\
DS Backw* & 2 & 3 & 2 & 3 & 2 & 3 & 2 & 3 & 3 & 3 \\
Oddity Learning & 49 & 55 & 53 & 54 & 52 & 54 & 51 & 54 & 52 & 54 \\
\hline
\end{tabular}

*) Variables that showed significant differences between the groups in the pre- test (ANOVA one way).

health education; it is well-known that health education should be done repeatedly during a long period of time to ensure a significant effect of the intervention. In the group receiving mebendazole and health education also did not showed significant improvement of cognitive function, and this might be caused by the lower worm burden in comparison with the group given mebendazole only.

This study showed that treatment of mebendazole was the most effective way of reducing worm burden. From Table 1 it could be seen that mebendazole treatment could reduce mean epg of $A$. lumbricoides from 2435 to 657 , which was a reduction of about $75 \%$ reduction, whereas health education alone decreased the epg to $40 \%$. The drastic reduction of mean epg of $A$. lumbricoides infection in the mebendazole group was followed by a significant increase of Coloured Progressive Matrices and Coding scores and an almost significant increase in Oddity scores. The infected children were obviously not very much impaired in their attention and concentration, therefore performance on Arithmatic and Digit Span were not affected by the different treatments. Coding and Oddity Learning involved a learning process, where speed, especially perceptual speed, and accuracy play important roles. The mebendazole group had a greater degree of worm infection compared to the other before the intervention. These children experience a drastic reduction of mean epg after the intervention. This might cause improvement in their cognitive processes, and therefore they became faster in seeing relationships, more accurate in their perception and had a better eye - hand coordination. These improvements lead to a better learning. The improvement in PM-C in the mebendazole group could also be explained in terms of a greater accuracy and speed in their perception in seeing relationships between the figures. The unsignificant improvement in the combined intervention might possibly due to the fact that they did not carry out what they were taught to do in the health education, thinking they were safeguarded by the medicine they received. In this group the education of the mother was lower in comparison to that of the mebendazole group, so that transfer of knowledge seemed less in this group. In this way, it could be explained why the improvement on the cognitive tests was slight, even less than the improvement in the placebo group. In general the children in this study experienced only light worm infection.

To see whether the different treatments had any effect in increasing the scores after intervention, an analysis of variance on the difference between pre- and post-intervention scores was done. But before commencing on the analysis, the equivalence of the groups in terms of intelligence, the intensity of Ascaris and Trichuris infection before intervention and mother's educational level was analysed first. One-way Analysis of Variance on pre-test scores was carried out . It was found that the four groups were not equivalent in terms of intelligence measured by the Coloured Progressive Matrices in the pre-test. Table 1 showed that the mebendazole group had the lowest mean, while two other groups (health education only and combined treatment of health education and mebendazole) had the highest means. It was also found that the groups were not comparable on the pre-intervention measurement of the amount of mean epg. Again the mebendazole group had the highest mean epg of $A$. lumbricoides and $T$. trichiura. 
The variable education of the mother was scored 0 if she did not finish elementary school, 1 if finished elementary school, 2 if finished junior secondary school and 3 if finished senior secondary school. Table 1 showed that on this variable the groups differed significantly. The mebendazole had the highest mean, next came the placebo group, while the lowest mean in mother's education was in the health education group. In the analysis of variance the variables : education of the mother, epg of $A$. lumbricoides and $T$. trichiura and PM-C scores were treated as covariates. Coding, Digit Span Forward and Digit Span Backward were also not comparable between the groups. These results did not cause any problem, because the Analysis of Covariance (ANCOVA) was done on the difference between pre- and post-intervention scores. The result of ANCOVA on difference scores is shown in Table 2.

The Table 2 showed the means of difference scores of the four groups on the variables in the study. The last column showed the significance of the $\mathrm{F}$ test.

From Table 2 it was evident that PM-C and Coding test for all the four groups showed significant improvement whereas for the other cognitive tests the overall groups did not show any significant improvement.

Kvalsvig et al ${ }^{14}$ had measured information processing rate using card sorting and cancellation tasks among South African children, and found that the parasite load significantly effect information processing and a 20- minute attention test. Nokes et.al, $1992^{10}$ reported that moderate to high worm burden of Trichuris trichiura infection had some influence on the auditory short-term memory and scanning and retrieval of long term memory on the 159 school children studied in Jamaica, and these cognitive tests showed significant improvement 9 weeks after treatment with albendazol. Recently, Mohammod ${ }^{15}$ reported from Malaysia that intestinal worm infections ( moderate and heavy infections of $A$. lumbricoides and Trichuris trichiura ) could effect the problem solving ability of the children tested. The total children recruited in his study was 331 school children of the third, fourth and fifth grade enrolled in 4 rural primary schools in Terangganu, Malaysia. The problem solving ability was measured by the test of Non-verbal Intelligence ( TONI-2). According to Mohammod, theoretically, intestinal helminths can adversely affect problemsolving ability through the following mechanisms : 1) Worms can cause chronic malnutrition of iron deficiency states through competition for nutrients with the host 2) Symptoms associated with worms such as anorexia, lethargy, abdominal pain and diarrhea may reduce attention span and ability to concentrate 3) Worms may adversely affect problem-solving ability through general disturbance of cortical functions "directly", perhaps through cytokines release from inflamatory reactions in the gut or by metabolites from the worms.

Table 2. Results of analysis of covariance on difference scores (post-test - pre-test scores)

\begin{tabular}{lccccc}
\hline VARIABLE & $\begin{array}{c}\text { Mebendazole } \\
\mathrm{n}=54\end{array}$ & $\begin{array}{c}\text { Health ed. } \\
\mathrm{n}=49\end{array}$ & $\begin{array}{c}\text { HE+Meb } \\
\mathrm{n}=48\end{array}$ & $\begin{array}{c}\text { Placebo } \\
\mathrm{n}=99\end{array}$ & Sig of F \\
\hline PM - C & 3.63 & -.61 & 1.40 & 1.73 & $.000^{* *}$ \\
Arithmetic & .78 & .37 & .38 & .74 & .763 \\
Coding & 12.61 & 6.12 & 4.69 & 6.60 & $.031^{*}$ \\
D.S. Forward & .43 & .49 & .23 & .54 & .573 \\
D.S. Backw & .65 & .41 & .48 & .64 & .706 \\
Oddity & 5.41 & .41 & 1.83 & 3.16 & .080 \\
A. Jurnbricordes & -1682.37 & -664.67 & -870.65 & 246.78 & $.000^{* *}$ \\
T. trichiura & -76.44 & 8.08 & 73.13 & 21.13 & $.001 * *$ \\
\hline
\end{tabular}

*) Significant at $\mathrm{p} \leq 0.05$

$* *$ ) Significant at $\mathrm{p} \leq 0.01$

***) ANCOVA on post test scores 


\section{CONCLUSIONS}

1. Cognitive tests i.e. Coloured Progressive matrices and Coding tests showed significant improvements after 6 months in the group treated with mebendazole for ascariosis. The group of children, aged $6-8$ years, improved in their ability in seeing relationship, was more accurate in perception and had better eye-hand coordination, leading to better learning. Therefore mebendazole treatment, had a significant effect on the cognitive function of a group of children with A. lumbricoides infection, although the infection was light grade.

2. No significant improvement in cognitive function was detected in the group with only health education due to a short term implementation of health education.

3. There was also no significant improvement in cognitive function in the group receiving anthelminthic together with health education.

4. No significant improvement in cognitive function found in the group receiving placebo.

Light degree of $A$. lumbricoides infection could effect the cognitive function of primary school children as was shown by an increase of PM-C and Coding scores after intervention. It seems that mebendazole treatment alone already showed improvement in cognitive function 6 months after treatment.

\section{Acknowledgement}

This study was funded by the Ministry of Research and Technology, Research Center for Science and Technology Project, and the National Research Council.

\section{REFERENCES}

1. Ismid IS, Margono SS, Anggarini S, Mahfudin H, Rasad R, Rasidi R and Rukmono B. The effect of mass treatment in different target groups on the dispersion of Ascaris eggs in the soil. Collected papers on the control of soil transmitted helminthiasis by the APCO Research group; 1983: Vol II, $231-7$.

2. Abidin SAN, Ismid IS, Margono SS. The prevalence and intensity of Ascaris, Trichuris infection with different treatment schedules. $14^{\text {th }}$ APCO Parasitologist's meeting; Tokyo, 1992.

3. Cooper ES, Bundy DAP. Trichuriasis. In: Pawlowski ZS ed. Balliere's clinical tropical medicine and communicable diseases. London : Baillicre Tindall, 1987:629-43.

4. Stephenson LS. Ascariasis. In: Stephenson IS ed. Impact of helminth infections on human nutrition. London : Taylor \& Francis, 1987:89-127.

5. Soemantri AG. Hubungan anemia kekurangan zat besi dengan konsentrasi dan prestasi belajar (Tesis Doktor). Semarang: FK Universitas Diponegoro, 1978.

6. Soewondo S, Husaini M, Pollit E. Effects of iron deficiency on attention and learning processes in pre-school children, Bandung, Indonesia. Am. J. Clin. Nutr. 1989; 50 : 667-674.

7. Soewondo S, Krisdinamurtirin J. Anemia and some aspects of mental functioning. The third Asean congress of nutrition; Jakarta: 1980

8. Soemantri AG. Preliminary Findings on iron suplementation and learning achievement of rural Indonesian children. Amer J Clin Nutr 1989; (50 suppl) : 698 - 702.

9. Nokes C, Cooper ES, Robinson BA, Bundy DAP. Geohelminth infection and academic assessment in Jamaican children. Trans R. Soc trop Med Hyg 1991; 85 : 272-3.

10. Nokes C, Grantham Mc gregor SM, Sawyer AW, Cooper ES, Bundy DAP. Parasitic helminth infection and cognitive function in school children. Proc R soc Lond 1992; 247:77 -81 .

11. Halloran ME, Bundy DAP, Pollitt E. Infectious disease and the Unesco basic education initiative. Parasitol Today 1989 5: $359-62$.

12. Pollitt E, Greenfield D, Saco Pollit C, Joos S. Validation of Attention and Retention Test in Studies on Malnutrition and Behavior in two cultures. In: Brozek J, Schurch B, editors. Malnutrition and Behavior : Critical Assessment of Key Issues. Laussane, Switzerland, Nestle Foundation, 1984.

13. Soewondo S. Pengaruh zat besi terhadap kognisi (Disertasi). Jakarta: Universitas Indonesia, 1991.

14. Kvalsvig JD, Coopan RM, Cannolly KJ. The effects of parasite infections on cognitive processes in children. Annals Trop Med Parasitol, 1991; 86(5):551-68.

15. Mohammod CG. Intestinal helminth infections adversely affect problem-solving ability of well-nourished, non anemic school children. $17^{\text {th }}$ APCO Parasitologist's meeting; Tokyo 1995. 